\title{
Understanding the process of information systems anc ICT curriculum development
}

\author{
Three Models
}

\author{
Arthur Tatnall and Bill Davey \\ School of Information Systems, Victoria University, Melbourne, Australia \\ School of Business Information Technology, RMIT University, Melbourne, Australia
}

\begin{abstract}
University curricula in Information Systems and ICT need to be frequently updated to take account of changing technologies and the uses made of these technologies. Many writers on the theory of curriculum give most attention to approaches to curriculum change based on research, development and diffusion models. This paper outlines some objections to the application of models of this type by describing how a university curriculum in information systems and ICT is built and rebuilt, and offers instead three alternate models; one based on curriculum negotiations, another on innovation translation from actor-network theory, and the third on an ecological model. In our discussion of these models, each will be shown to allow for the inclusion of a richer level of complexity than research, development and diffusion models when describing the curriculum development process.
\end{abstract}

Key words: information systems, ICT, curriculum change, innovation

\section{INTRODUCTION}

The area of Information and Communications Technologies (ICT), and in particular Information Systems (IS), is subject to constant and continuing change as new development methodologies and techniques are devised and new technologies appear. Curriculum in this area must, necessarily, undergo frequent revision. This paper compares several models of how curriculum change occurs in higher education ICT courses.

The process of curriculum development is often described by some form of research, development and diffusion model (Nordvall, 1982) which

The original version of this chapter was revised: The copyright line was incorrect. This has been corrected. The Erratum to this chapter is available at DOI: 10.1007/978-0-387-35609-9_29 
suggests a rational and orderly transition from research to development to diffusion to adoption.

Research $\rightarrow$ Development $\rightarrow$ Production $\rightarrow$ Dissemination $\rightarrow$ Adoption

Although often used to explain how curriculum change occurs in schools, models like this are also sometimes applied to the development of higher education curricula. These models suggest that curriculum development is a logical process of matching the objectives of a program to curriculum elements. In this paper we argue that models like this are inappropriate in explaining the much more complex process that we contend occurs.

\section{CURRICULUM DEVELOPMENT MODELS}

Information systems curriculum development in a university takes place in an environment containing academic and industrial elements, and artefacts such as development tools and methodologies. Pitman (1981) argues that the process of curriculum development involves a set of complex negotiations between those writing its details. The 'parties' to the negotiation can include things like the 'base positions' of individual academic staff, a particular programming language, a specific teaching package, filling a particular industry career-niche for students, and a specific set of 'important concepts'.

Tatnall (2000) proposes that IS curriculum can best be seen as an actornetwork involving contributions from both human and non-human actors. Actor-Network Theory (ANT) sees innovation as involving the translation of any idea into new forms by potential adopters. A curriculum innovation is translated into a form appropriate to a particular university, or group of academics, that is probably different from the forms in which it appears in elsewhere.

Using the work of Truran (1997) on the development of mathematics curriculum in Australia, Tatnall and Davey (2002) have proposed an ecological model to explain divergence between courses. We suggest that educational systems may be seen as ecosystems containing interacting individuals. The interactions will sometimes involve co-operation and sometimes competition, and may be interpreted in terms of ecological forces along with mechanisms for minimising energy expenditure.

Curriculum development in a university information systems department is a complex process, and in this paper we use several models to investigate frameworks for understanding it. We contend that without understanding the complexities of this process, effective IS curriculum change is not possible. 


\section{A MODEL FOR CURRICULUM NEGOTIATION}

Many entities are involved in the process of developing or adapting an ICT curriculum and a number of people and groups take part in the negotiations that result in the curriculum 'product' that finally appears. To see how this occurs, consider a situation involving just three of these parties: the Course Advisory Committee for the School of Information Systems, the IS academic teaching staff, and the University administration. The Course Advisory Committee will typically consist of representatives from the computer industry and professional bodies like the Australian Computer Society. It will probably adopt a position that the IS curriculum should reflect the needs of industry and so have an industry focus. The academic staff who will teach the curriculum will be concerned, apart from its content, with the educational needs of their students and what can usefully be taught to them. They will have more of a teaching focus. The university administration will focus mainly on the cost and availability of the resources required to deliver the curriculum, and on the maintenance of academic standards.

\subsection{Development of the model}

To understand and anticipate these actions, we need a broad conceptual framework. Pitman (1981) argues that the 'product' originally devised by a curriculum developer is modified in a series of negotiations with mediators, teachers and students before being adopted. He argues that each of these parties begins negotiations from their own 'world' viewpoint, trying to convince others of the value of their claims to determine what is required. A slight modification of this model would see these negotiations, in the context of a university information systems curriculum, as being between the Course Advisory Committee, university academics, and university administrators.

\subsection{Application of the model}

The curriculum development process involves each of these groups meeting to negotiate the curriculum content according to the way they see it. This process is much more complex than the logical selection of material deemed important to fill the needs of business, or by a group of academics, as each party will argue and compromise, to some extent, during the negotiations. 


\subsection{Advantages of the model}

An important aspect of this model is seeing the curriculum as a product that is produced by joint, negotiated actions of several parties. The final product is then something that does not belong to any one of the parties, and in which all parties can find something of their own input. The model regards the final product as a true negotiation between these parties, but omits one party that we regard as essential to the negotiations: the technology itself. The next approach we will discuss will attempt to redress this omission.

\section{AN ACTOR-NETWORK APPROACH TO ICT CURRICULUM DEVELOPMENT}

\subsection{Development of the model}

Actor-network theory (Callon, 1986; Latour, 1986; Law, 1992) reacts against the idea that characteristics of humans and social organisations exist that distinguish their actions from the inanimate behaviour of technological and natural objects. It adopts an anti-essentialist position in which it rejects there being some difference in 'essence' between humans and non-humans. In the model of translation as proposed in actor-network theory, Latour (1986) maintains that the movement of an innovation is in the hands of people, each of whom shapes it to their own ends. Latour argues that it is not just a matter of each of the actors in the chain either resisting the innovation or transmitting it in the form they received it, but that their shaping of the innovation is essential for its continued existence. In this they are actors, not just clients, and everyone involved translates, or shapes the innovation according to their own needs.

\subsection{Advantages of the model}

A translation model requires the focus to be on understanding how actornetworks are created, strengthened and weakened, rather than on causes and effects. The key to innovation is the creation of a powerful enough consortium of actors to carry it through, and calls for strategies aimed at the enrolment of others. Latour (1986) maintains that this is done by 'interesting' these others and then getting them to follow our interests. 


\subsection{Application of the model}

We will briefly relate the introduction of the programming language Visual Basic (VB) into the information systems degree at an Australian university (Tatnall, 2000; Tatnall and Davey, 2001). The story begins when Fred, a university IS academic, first encountered VB when working on an external consulting job. Fred was so impressed that he decided he must introduce VB to his students. The particular subject taken by Fred where he intended introducing VB was one involving systems design. It was not a programming subject and this meant that only the 'visual' aspect of VB was needed. As only some aspects of VB (the visual parts) were required, Fred translated it from a general purpose programming language into a package for screen design. In this way the VB he adopted for this subject should be seen as a different innovation from the VB used in teaching programming in a computer science course.

\section{AN ECOLOGICAL METAPHOR FOR ICT AND IS CURRICULUM DEVELOPMENT}

\subsection{Development of the model}

Community and developmental ecology (Townsend, Harper and Begon, 2000) offer two principles underlying the ecology discipline: organisms behave in ways that optimise the balance between energy expenditure and satisfaction obtained, and they operate within a competitive environment that ensures only the efficient will survive.

An ecosystem can be considered to contain producers, consumers and decomposers. A classical definition is "a natural unit of living and non-living parts that interact to produce a stable system in which the exchange of materials between the living and non-living parts follows a circular path" (Ville, 1962). Habitat, ecological niches, and exploitation of resources in predator-prey interactions, competition, and multi-species communities (Case, 2000) are all considerations. Many different individuals and species typically occupy any given ecosystem, and can be considered to interact in different ways. 


\subsection{Application of the model}

An ecosystem contains a high degree of complexity due to the large number of species living in it, and to the variety of interactions possible between each of these. Tatnall and Davey (2002) suggest that a useful correspondence may be seen between these ideas and curriculum development. We argue that a university IS curriculum may be seen as an ecosystem, and that interactions within this can be analysed in terms of ecological concepts such as competition models, co-operative behaviour, predator-prey relationships, niche-development and energy expenditure. The 'ecosystem' represented by the curriculum in a university IS Department contains (at least) the following 'species': lecturers, researchers, students, professional bodies, university administrators, Course Advisory Board members and representatives of the computer industry. The 'environment' also contains many inanimate objects relevant to the formation of the curriculum, including: computers, programming languages, textbooks, lecture rooms, analysis and design methodologies, networks, laboratories, programming manuals, and so on.

In IS curriculum development we should look at factors, both human and artefact, to see which are expected to compete or co-operate and become part of the surviving outcome. A non-human stakeholder like a development tool or methodology will either co-operate with the environment, compete successfully, or die out.

\subsection{Advantages of the model}

Researchers investigating curriculum development must use language in framing their research questions. This language often reflects a general viewpoint from the field under investigation, and will always embody some metaphor for the principle components of this field. Many of the metaphors used in curriculum development are taken from areas such as manufacturing or the physical sciences, but any investigation of development processes in rapidly changing areas such as information systems shows that a common factor is complexity. One discipline to have found suitable metaphors to accommodate complexity is that of ecology, and we contend that ecological principles appear to provide good descriptions of common curriculum development activities. The ease with which the metaphor can be used to describe actions within IS curriculum development shows that it can be useful as a set of language elements that might lead the researcher to framing useful questions that do not trivialise the complexity of the field. 


\section{CONCLUSIONS: COMPARING THE MODELS}

The choices of individual academics, or groups of academics, to adopt or ignore a new concept or technology, and to compete or co-operate, are a significant factor in IS curriculum change. A model that allows us to more accurately view the processes surrounding curriculum development in a rapidly changing knowledge domain will be based on complexity and interaction of individual factors. Current models allow for neither of these aspects and hence have consistently failed to accurately reflect practice in ICT curriculum development. Three models have been presented here that overcome these difficulties and are characterised in the following table.

\begin{tabular}{|l|l|l|}
\hline \multicolumn{1}{|c|}{ Model } & \multicolumn{1}{c|}{ Characteristics } & \multicolumn{1}{c|}{ Advantages } \\
\hline Negotiation & $\begin{array}{l}\text { Looks at the set of } \\
\text { dialogs between } \\
\text { competing forces. }\end{array}$ & $\begin{array}{l}\text { Incorporates the view that } \\
\text { differences of opinion must be } \\
\text { accommodated. }\end{array}$ \\
\hline Actor-Network & $\begin{array}{l}\text { Looks at the interactions } \\
\text { between all human and } \\
\text { non-human actors in the } \\
\text { development process. }\end{array}$ & $\begin{array}{l}\text { Allows for flexibility in } \\
\text { considering all the factors that } \\
\text { influence outcomes. }\end{array}$ \\
\hline $\begin{array}{l}\text { Ecological } \\
\text { model }\end{array}$ & $\begin{array}{l}\text { Uses the language and } \\
\text { principles of ecology. }\end{array}$ & $\begin{array}{l}\text { Arises from a knowledge domain } \\
\text { that embraces complexity. }\end{array}$ \\
\hline
\end{tabular}

Table 1: Characteristics of the three curriculum development models

ICT education places particular stresses on the curriculum developer as few other areas have paradigm changes that occur so fast. If the developer is to ensure the best outcome in terms of new curriculum statements, then a clear understanding of the real processes in action is needed. Each of the models described in the paper allow the planner to identify the real, as opposed to the formal processes of ICT curriculum development, and hence attempt to empower the planner in this important task.

\section{REFERENCES}

Callon, M. (1986). "The Sociology of an Actor-Network: The Case of the Electric Vehicle". Mapping the Dynamics of Science and Technology. Callon, M., Law, J. and Rip, A. London, Macmillan Press: 19-34.

Case, T. J. (2000). An Illustrated Guide to Theoretical Ecology. New York, Oxford University Press. 
Latour, B. (1986). "The Powers of Association". Power, Action and Belief. A new sociology of knowledge? Sociological Review monograph 32. Law, J. London, Routledge \& Kegan Paul: 264-280.

Law, J. (1992). "Notes on the Theory of the Actor-Network: Ordering, Strategy and Heterogeneity." Systems Practice 5(4): 379-393.

Nordvall, R. C. (1982). "The process of change in higher education institutions". Washington DC, American Association for Higher Education.

Pitman, A. (1981). "The Necessary Distortion of Disseminated Innovations." Journal of Curriculum Studies 13(3): 253-265.

Tatnall, A. (2000). "Innovation and Change in the Information Systems Curriculum of an Australian University: a Socio-Technical Perspective". PhD thesis. Education. Rockhampton, Central Queensland University.

Tatnall, A. and Davey, B. (2001). How Visual Basic Entered the Curriculum at an Australian University: An Account Informed by Innovation Translation. Challenges to Informing Clients: A Transdisciplinary Approach (Informing Science 2001), Krakow, Poland.

Tatnall, A. and Davey, B. (2002). "Information Systems Curriculum Development as an Ecological Process". IT Education: Challenges for the $21^{\text {st }}$ Century. Cohen, E. Hershey, PA, Idea Group Publishing: 206-221.

Townsend, C. R., Harper, J. L. and Begon, M. (2000). Essentials of Ecology. Massachusetts, Blackwell Science.

Truran, J. M. (1997). Reinterpreting Australian Mathematics Curriculum Development Using a Broad-spectrum Ecological Model. Old Boundaries and New Frontiers in Histories of Education: Australian and New Zealand History of Education Society Conference, Newcastle, Australia, The University of Newcastle.

Ville, C. A. (1962). Biology. Philadelphia, W. B. Saunders Company. 